\title{
EFEK ANTIHIPERKOLESTEROLEMIA KITIN CANGKANG UDANG WINDU (Penaeus monodon) SECARA INVIVO PADA KELINCI (Oryctolagus cuniculus)
}

\author{
Muammar Fawwaz \\ Fakultas Farmasi Universitas Muslim Indonesia \\ Email : fawwaz_pharm@yahoo.com
}

\begin{abstract}
The reasearch test effect anthypercholesterolemia Chytosan Windu Shrimp Shell with aimed to know the effect to decrease the total blood cholesterol degree on adult rabbit. These research include 3 group, namely 1 group of control and 2 groups of examined namely chytosan $5 \%$ and $10 \% \mathrm{w} / \mathrm{v}$. The observation applied with measure of the total blood cholesterol degree on adult rabbit before induction of cholesterol, then inducted of cholesterol as long as 7 days, then observed cholesterol degree, and then its gived chytosan $400 \mathrm{mg} / \mathrm{kgBB}(5 \% \mathrm{w} / \mathrm{v})$ and 800 $\mathrm{mg} / \mathrm{kgBB}(10 \% \mathrm{w} / \mathrm{v})$ at the $8^{\text {th }}$ and measured again of the total blood cholesterol degree after examined Chytosan at concentration $400 \mathrm{mg} / \mathrm{kgBB}(5 \% \mathrm{w} / \mathrm{v})$ dan 800 $\mathrm{mg} / \mathrm{kgBB}(10 \% \mathrm{w} / \mathrm{v})$, conduct decreasing of total blood cholesterol degree on adult rabbit.
\end{abstract}

Key Word : Antihypercholestrolemia, Penaeus monodo, Oryctolagus cuniculus, Invivo

\section{PENDAHULUAN}

Lemak merupakan sumber energi yang memberikan kalori paling tinggi, selain sebagai salah satu sumber energi lemak atau khususnya kolesterol juga merupakan zat yang dibutuhkan oleh tubuh terutama untuk membentuk dinding sel dalam tubuh dan sebagai bahan dasar pembentukan hormon-hormon steroid, namun jika kolesterol dalam tubuh berlebih akan tertimbun dalam dinding pembuluh darah dan menimbulkan aterosklerosis dan menjadi penyebab utama jantung koroner. Ada beberapa jenis obat antihiperkolesterolemia yang digunakan untuk menurunkan kadar kolesterol darah, seperti kolestiramin, kolestipol, golongan statin, asam nikotinat, probukol, dan derivat asam fibrat, akan tetapi mengingat efek samping obat tersebut, maka dianggap perlu untuk mengembangkan obat yang lebih alamiah.

Makassar merupakan daerah penghasil budidaya laut yang cukup besar yang salah satu diantaranya adalah udang windu, dimana hasil 
budidaya udang windu sebagian besar di ekspor dalam keadaan bersih dari cangkang, sehingga cangkang udang windu merupakan limbah industri di daerah ini, maka perlu dilakukan pemanfaatan lebih jauh.

Cangkang udang windu dapat diolah menjadi kitin melalui proses demineralisasi dan deproteinisasi, kemudian dilanjutkan dengan proses deasetilasi sehingga terbentuklah kitosan. Kitosan merupakan senyawa yang bermuatan parsial positif kuat sehingga mampu menarik molekul yang bermuatan parsial negatif seperti minyak dan lemak. Telah dilakukan penelitian kitosan terhadap penurunan kadar kolesterol secara invitro oleh Sanusi (2004).

\section{METODE PENELITIAN}

\section{Alat dan bahan}

Alat yang digunakan yaitu alat-alat gelas, fotometer, kateter, mouth block, oven, stop watch, sentrifuge, termometer, timbangan analitik, timbangan kasar, timbangan hewan

Bahan yang digunakan Air suling, Alkohol, Asam Klorida, Kolesterol murni, Kuning telur, Lemak hewan, Minyak kelapa, Natrium Hidroksida, Natrium CMC, Propiltiourasil, Reagen penguji kolesterol total.

\section{Prosedur Kerja}

\section{a. Pengolahan sampel}

Cangkang udang dicuci dengan air mengalir dan dikeringkan di bawah sinar matahari sampai kering, kemudian diserbukkan.

b. Deproteinasi

Cangkang udang yang telah diserbukkan dicampur dengan larutan $\mathrm{NaOH} 3,5 \%$ dengan perbandingan antara pelarut dan cangkang udang 6 :

1. Diaduk sampai merata sekitar satu jam. Selanjutnya dibiarkan beberapa saat, lalu dipanaskan pada suhu $80^{\circ}$ $90^{\circ} \mathrm{C}$ selama satu jam, kemudian larutan disaring dan didinginkan sehingga diperoleh residu padatan yang kemudian dicuci dengan air sampai $\mathrm{pH}$ netral dan dikeringkan pada suhu $80^{\circ} \mathrm{C}$ selama 24 jam atau dijemur sampai kering.

\section{c. Demineralisasi}

Dicampur asam klorida $1,25 \mathrm{~N}$ dengan perbandingan 10 : 1 untuk pelarut dibandingkan dengan kulit udang, lalu diaduk merata sekitar satu jam. Dibiarkan sebentar, kemudian dipanaskan 
pada suhu $90^{\circ} \mathrm{C}$ selama satu jam. Residu berupa padatan dicuci dengan air sampai $\mathrm{pH}$ netral dan selanjutnya dikeringkan dalam oven pada suhu $80^{\circ} \mathrm{C}$ selama 24 jam atau di jemur sampai kering.

\section{d. Deasetilisasi}

Deasetilisasi kitin yang diperoleh dari hasil demineralisasi dan deproteinisasi menjadi kitosan, dibuat dengan menambahkan $\mathrm{NaOH} \quad 50 \%$ dengan perbandingan 20: 1 (pelarut dibanding kitin). Diaduk sampai merata selama 1 jam dan dibiarkan sekitar 30 menit, lalu dipanaskan selama 90 menit dengan suhu $140^{\circ} \mathrm{C}$. Larutan kemudian disaring untuk mendapatkan residu berupa padatan, lalu dilakukan pencucian dengan air sampai $\mathrm{pH}$ netral, kemudian dikeringkan dengan oven suhu $70^{\circ} \mathrm{C}$ selama 24 jam atau dijemur sampai kering. Bentuk akhir dari kitosan bisa berbentuk serbuk maupun serpihan.

\section{e. Penyiapan kolesterol}

Kolesterol murni yang diberikan untuk meningkatkan kadar kolesterol darah kelinci dibuat dengan cara mendispersikan kolesterol murni $1 \%$ dalam minyak kelapa.

\section{f. Pembuatan air minum yang} mengandung propiltiourasil $0,01 \%$

Air minum untuk hewan coba disiapkan dengan menambahkan propiltiourasil $0,01 \%$ dibuat dengan cara menimbang tablet yang telah dihaluskan yang setara dengan $100 \mathrm{mg}$ propiltiourasil dan melarutkannya dalam $1000 \mathrm{ml}$ air suling.

\section{g. Pemilihan dan penyiapan} hewan uji

Hewan uji yang digunakan adalah kelinci jantan dewasa berbadan sehat dengan aktifitas normal, dan berat badan $1,5-2,0 \mathrm{~kg}$, dibagi dalam empat kelompok.

h. Penyiapan kitosan 5\% dan $10 \%$

Kitosan dibuat dengan menimbang serbuk kitosan sesuai dengan konsentrasi yang diinginkan. Untuk konsentrasi $5 \%$ dan $10 \%$ masing-masing ditimbang $5 \mathrm{~g}$ dan $10 \mathrm{~g}$ kemudian di 
dispersikan dalam Na.CMC $(1 \% \mathrm{~b} / \mathrm{v})$.

i. Perlakuan terhadap hewan uji

Kelinci yang akan digunakan, dipelihara dalam kandang percobaan untuk menyesuaikan diri dengan lingkungannya,

dipuasakan selama 18 jam tetapi tetap diberi air minum. Sebelum diberi perlakuan terlebih dahulu dilakukan pengukuran kadar kolesterol darah awal terhadap semua kelinci. Kelinci kemudian dibagi secara acak dalam kelompok berikut :

1) Kelompok kontrol

Kelinci jantan diberi diet kolesterol secara oral dan air minum yang mengandung propiltiourasil $0,01 \%$ selama 7 hari. Lalu diambil contoh darahnya untuk melihat kenaikan kadar kolesterol darahnya, dan tidak diberi kitosan.
2) Kelompok perlakuan

Kelinci jantan diberi diet kolesterol secara oral dan air minum yang mengandung propiltiourasil $0,01 \%$ selama 7 hari. Lalu diambil contoh darahnya untuk melihat kenaikan kadar kolesterol darahnya, dan diberi kitosan secara oral selama sehari.

a. Kelompok II, diberi kitosan dengan konsentrasi $5 \%$

b. Kelompok III, diberi kitosan dengan konsentrasi $10 \%$

j. Pengumpulan dan Analisis Data

Data yang diperoleh dari hasil pengamatan diolah dengan analisis Rancangan Acak Kelompok (RAK), kemudian dilakukan pengamatan antara perlakuan yang ada dengan melihat perbedaan yang nyata dari tabel anava. 


\section{HASIL PENELITIAN}

Tabel 1. Hasil pengamatan efek Antihiperkolesterolemia kitosan cangkang udang windu (Penaeus monodon) terhadap kelinci (Oryctolagus cuniculus)

\begin{tabular}{ccccc}
\hline \multirow{2}{*}{ KELOMPOK } & \multirow{2}{*}{ REPLIKASI } & \multicolumn{3}{c}{ PERLAKUAN } \\
\cline { 3 - 5 } & & To & $\mathbf{T}_{\mathbf{1}}$ & $\mathbf{T}_{\mathbf{2}}$ \\
\hline \multirow{2}{*}{ Kontrol } & 1 & 42 & 58 & 58 \\
& 2 & 60 & 61 & 61 \\
& 3 & 43 & 88 & 88 \\
\hline \multirow{2}{*}{ Kitosan 5\% } & 1 & 43 & 88 & 69 \\
& 2 & 31 & 58 & 33 \\
\hline \multirow{2}{*}{ Kitosan 10\% } & 3 & 12 & 62 & 40 \\
& 1 & 37 & 107 & 57 \\
& 2 & 25 & 64 & 47 \\
\hline
\end{tabular}

Keterangan :

To : Kadar Kolesterol darah kelinci sebelum diet $(\mathrm{mg} / \mathrm{dL})$

$\mathrm{T}_{1} \quad$ : Kadar Kolesterol darah kelinci setelah diet $(\mathrm{mg} / \mathrm{dL})$

$\mathrm{T}_{2} \quad$ : Kadar Kolesterol darah kelinci setelah perlakuan $(\mathrm{mg} / \mathrm{dL})$

\section{PEMBAHASAN}

Kolesterol merupakan penyakit yang perlu diwaspadai, karena merupakan salah satu penyakit mematikan di dunia. Kenaikan kadar kolesterol darah melebihi normal menyebabkan penyumbatan pembuluh darah atau arteriosklerosis, yang merupakan salah satu pencetus penyakit jantung koroner.

Melangkah dari fakta tersebut dan juga dengan melihat kenyataan bahwa obat-obat sintetik yang digunakan sebagai antihiperkolesterol relatif memiliki efek samping yang lebih besar dan bahkan resiko komplikasi kemungkinan besar dapat terjadi. Dengan alasan inilah sehingga sebagai seorang mahasiswa farmasi merasa perlu melakukan terobosan baru dalam hal penemuan obat hiperkolesterol yang lebih aman dan efektif.

Untuk penelitian ini dipililah sampel kitosan yang secara invitro telah diteliti dapat menurunkan kadar kolesterol total darah, selain itu juga didasarkan atas sifat kimia kitosan yang lebih bermuatan parsial positif kuat yang mampu mengikat lemak, sehingga perlu dilakukan penelitian lanjutan mengenai efeknya sebagai antihiperkolesterolemia secara invivo pada kelinci (Oryctolagus cuniculus).

Langkah awal yang dilakukan yakni preparasi kitosan yang dibuat dengan menyiapkan serbuk cangkang udang sebanyak 100 g, yang kemudian dilanjutkan dengan proses demineralisasi dan deproteinisasi, dari 
hasil proses ini maka didapatkanlah 67

g kitin. Untuk mendapatkan kitosan, maka kitin tersebut diproses lebih lanjut dengan deasetilasi, sehingga menghasilkan kitosan sebesar $50 \mathrm{~g}$. Dari proses deasetilasi inilah yang menyebabkan kitosan bermuatan parsial positif kuat sehingga mampu mengikat senyawa yang bermuatan parsial negatif, misalnya kolesterol.

Seiring dengan penyiapan kitosan, dipersiapkan pula hewan coba kelinci dewasa (Oryctolagus cuniculus) dengan jumlah 9 ekor. Dari ke-9 kelinci tadi dibagi ke dalam tiga kelompok, kelompok I sebagai kontrol, kelompok II diberi kitosan 5\% dan kelompok III diberi kitosan $10 \%$. Tiap kelompok diukur kadar kolesterol total darah awal sebelum diet kolesterol, dan hasil pengukuran tersebut didapatkan kadar kolesterol total untuk kelompok I $48,33 \mathrm{mg} / \mathrm{dl}$, untuk kelompok II 28,66 $\mathrm{mg} / \mathrm{dl}$, dan untuk kelompok III 29 $\mathrm{mg} / \mathrm{dl}$. Setelah itu setiap kelompok diberi diet kolesterol dan minuman yang mengandung propiltiourasil selama 7 hari dengan tujuan untuk meningkatkan kadar kolesterol darah pada masing-masing kelinci tersebut. Hasil pengukuran kolesterol total darah setelah diet kolesterol diperoleh data untuk kelompok I $69 \mathrm{mg} / \mathrm{dl}$, kelompok II 69,33 mg/dl, dan kelompok III 92,66 mg/dl. Metode pengukuran kadar kolesterol total dilakukan secara enzimatis dengan menggunakan alat Fotometer.

Kelinci yang telah diberi diet kolesterol tadi, kemudian diberi perlakuan masing-masing, kelompok I sebagai kontrol hanya diberi makanan standar dan tidak diberi kitosan, kelompok II diberi makanan standar dan kitosan $400 \mathrm{mg} / \mathrm{kgBB}(5 \% \mathrm{~b} / \mathrm{v})$, sedangkan kelompok III diberi makanan standar dan kitosan 800 $\mathrm{mg} / \mathrm{kgBB}(10 \% \mathrm{~b} / \mathrm{v})$. Setelah perlakuan tersebut, maka dilakukan pengukuran kadar kolesterol total darah pada selang waktu 1 hari. Dari hasil pengamatan diperoleh kadar kolesterol total darah setelah perlakuan untuk kelompok | $69 \mathrm{mg} / \mathrm{dl}$, kelompok II 47,33 $\mathrm{mg} / \mathrm{dl}$, sedangkan untuk kelompok III 55,33 mg/dl.

Dari hasil analisis data yang telah dilakukan mengenai efek antihiperkolesterolemia kitosan udang windu (Penaeus monodon) terhadap kelinci (Oryctolagus cuniculus), menunjukkan bahwa kitosan udang windu (Penaeus monodon) memiliki efek antihiperkolesterolemia pada konsentrasi $400 \mathrm{mg} / \mathrm{kgBB}(5 \% \mathrm{~b} / \mathrm{v})$ dan $800 \mathrm{mg} / \mathrm{kgBB} \quad(10 \% \mathrm{~b} / \mathrm{v})$, efek antihiperkolesterolemia yang ditimbulkan antara kedua variasi 
konsentrasi tersebut dengan kontrol menunjukkan perbedaan yang nyata, tetapi antara konsentrasi $400 \mathrm{mg} / \mathrm{kgBB}$ $(5 \% \mathrm{~b} / \mathrm{v})$ dengan $800 \mathrm{mg} / \mathrm{kgBB}$ $(10 \% \mathrm{~b} / \mathrm{v})$ tidak menunjukkan perbedaan yang nyata.

Dengan demikian dapat disimpulkan bahwa pemberian kitosan udang windu (Penaeus monodon) pada kelinci (Oryctolagus cuniculus) secara invivo efektif menurunkan kadar kolesterol darah.

\section{KESIMPULAN}

Dari hasil penelitian yang telah dilakukan dapat disimpulkan bahwa pemberian kitosan $400 \mathrm{mg} / \mathrm{kgBB}$ $(5 \% \mathrm{~b} / \mathrm{v})$ sampai $800 \mathrm{mg} / \mathrm{kgBB}$ $(10 \% \mathrm{~b} / \mathrm{v})$ dapat menurunkan kadar kolesterol total darah.

\section{DAFTAR PUSTAKA}

Clarke, A.C., 2007, Demineralisasi : Wattpad Company, (Online), (http://wattpad.com/Inc, diakse s 15 Juli 2007).

Guyton, A.C., 1994, Buku Ajar Fisiologi Kedokteran, Bagian III, Edisi 7, Penerbit Buku Kedokteran EGC : Jakarta.

Heslet, L., 1991, Cholesterol, Terjemahan Anton Adwiyoto, Mega Point : Jakarta.

Hirano., 1976, An Encyclopedia of Chemicals and Drugs, Merc \& Co.Inc : USA.

Jae, K.W., 2005, Kolesterol : Yayasan Jantung Indonesia, (Online), (http://yayasan jantung indonesia.com, diakses 12 Juli 2007).

Kaplan, M.D., \& Stemler, M.D ., 1991, Pencegahan Penyakit Jantung Koroner, Penerbit Buku Kedokteran EGC : Jakarta.

King, W.M., 2003, Cholesterol and Bile Metabolism : M.King (Online), (http://www.mking@medicine.i ndstate.edu, diakses 11 September 2007.

Koolman, J., \& Rohm, H.K., 2001, Atlas Berwarna \& Teks Biokimia, EGC : Jakarta

Kurnia, F.H., \& Susanto., T. 2002, Faktor-faktor yang Berpengaruh Terhadap Tahap Deproteinasi : Influencing Factors to Deproteination Stage Using Protease Enzyme During Chitin Production From Crab (Portunus pelagicus) Shell, (Online), (http://faktorfaktor.Adb.pdf , diakses 10 Juli 2007).

Kusumawati, Y., 2006, Mengenal Lebih Dekat Kitosan : Pikiran Rakyat Bandung, (Online), (mailto:pdr.pikiranrakyat.co.id, diakses 10 Juli 2007.

Malole, M.B.M., et al., 1989, Penggunaan Hewan-Hewan Percobaan di Laboratorium, Depkes RI : Jakarta.

Maskoeri., 1989, Zoologi Vertebrata, Erlangga : Surabaya

Marganof., 2003, Potensi Limbah Udang Sebagai Penyerap Logam Berat di Perairan : 
Marganof,

(Online),

(Marganof@yahoo.com,

diakses 10 Juli 2007).

McGilvery, R.W., \& Goldstein, W.G., 1996, Biokimia, Edisi III, Airlangga University Press : Surabaya.

Murray, R.K., dkk., 2003, Biokimia Harper, Edisi 25, Penerbit Buku Kedokteran EGC : Jakarta.

Mulja, M., \& Syahrani, A., 1990, Aplikasi Analisis Spektrofotometri UV-VIS, Mecphiso Grafika : Surabaya.

Prasetiyo, K.W., 2006, Pengolahan Limbah Cangkang Udang : Teropong Kompas, (Online), (http://kompas.com/kcm/,diaks es 12 Juli 2007).

Rismana, E., \& Srijanto, B., 2005 , Teknologi Proses Produksi Kitin-Kitosan: Kedai IPTEK PKT-BPPT, (Online), (http://lc.bppt.go.id/iptek, diakses 10 Juli 2007).

Sanusi, M., 2004, Konversi Kitin Menjadi Kitosan Dan Uji Antihiperkolesterol Secara Invitro, Tesis tidak diterbitkan. Makassar : Program Pascasarjana. Farmasi. Universitas Hasanuddin.

Selamihardja, N., 2008, Kiat Mengelola Kolesterol Tinggi : Intisari, (Online), (http://Intisari.com, diakses 5 Februari 2008).

Srigustiana, L., 2006, Uji Efek Antihiperkolesterolemia Infus
Daun Keji Beling (Strobilanthes crispus BL) Pada Kelinci Jantan, Tesis tidak diterbitkan. Makassar : Program Sarjana. Farmasi. Universitas Muslim Indonesia.

Sitopoe, M., 1992, Kolesterol Fobia, Keterkaitannya Dengan Penyakit Jantung, Gramedia Pustaka Utama : Jakarta.

Sidik, et all., 1993, Penapisan Farmakologi, Pengujian Fitokimia dan Pengujian Klinik, Phytomedica : Jakarta.

Sinaga, E., 2002, Kiat Menurunkan Kadar Kolesterol Darah : Republika, (Online), (http://republika.co.id/htm, diakses 5 Februari 2008).

Wirahadikusuma., 1985, Biosintesis Karbohidrat, Protein dan Lipid, UI Press: Jakarta

Widodo, A., \& Muslihatin,W., 2005, Kitosan Dari Sisa Udang Sebagai Koagulan Limbah Cair Industri Tekstil, Karya Tulis IImiah Institut Teknologi Sepuluh Nopember Surabaya.

Yuliana, D., 2004, Uji Efek Soyghurt Hasil Fermentasi Lactobacilus casei subps casei $R$-35 dan Streptococcus thermophilus Terhadap Penurunan Kadar Kolesterol Darah Total Pada Kelinci Jantan (Oryctolagus cuniculus). Tesis tidak diterbitkan. Makassar : Program Sarjana. Farmasi. Universitas Hasanuddin. 